"the National Socialist weltanschauung" as well as "the National Socialist philosophy and theory of science" (354).

${ }^{20}$ See Lothar Samson, "Nachwort," GA 2, 414ff.; Karl-Siegbert Rehberg, "Nachwort des Herausgebers," GA 3, 753f.; George Leaman, Heidegger im Kontext, 41; Gerwin Klinger, 'Freiheit als 'freiwillige Aufgabe der Freiheit.' Arnold Gehlens Umbau des Deutschen Idealismus," Deutsche Philosophen 1933, hrsgg. v. Wolfgang Fritz Haug, Hamburg: Argument-Verlag, 188ff.

${ }^{21}$ At one place Kant is for example frankly called a "prepragmatist" (GA 3, 639). For a connection of Hobbes to James and Dewey, with a reference to Baumgarten, see GA 3, 579f.

${ }^{22}$ Gehlen in this chapter several times points to the close relation between his notion of "supreme systems of guidance" and Alfred Rosenberg's notion of "disciplinary ideal orders [Zuchtbilder]" (cf. GA 3, 710, 733, 742).

${ }^{23}$ In the article Der Idealismus und die Gegenwart from 1935 Gehlen states that "the National Socialist weltanschauung is total, i.e., lays claim to penetrate every area of life and to bring it in correspondence with its fundamental views" (GA 2, 354). In comparison the task of a weltanschauung in Der Mensch seems to be more restricted; it shall not interfere in the tasks of science and (in a restricted sense) religion. How this restriction is compatible with the claim that science too is in need of guidance isn't quite clear to me.

${ }^{24}$ It should be noted that this is a weltanschauung in which an antisemitism, as far as I can see, plays no essential role. Gehlen's philosophical anthropology is on the contrary said to be a "science of utmost importance, just because it's situated before every science of race" (GA 3, 487).

\section{AUthoritarianism IN}

THE NeTHERLANDS: Mission COMPLETED?

\section{DOWNWARd TRENDS IN AUTHORTTARIANISM IN THE NeTHERLANDS 1970-1992 WITH AN INTERNATIONAL COMPARISON OF WORLD DATA}

\author{
Jos D. Meloen
}

University of Leiden, The Netherlands

\section{Abstract}

Three basic bypotheses on authoritarianism in The Netherlands are proposed. A composite Middendorp data set was used, that included five national random samples in The Netherlands: 1970, 1975, 1980, 1985 and 1992. The first bypothesis maintains that the authoritarianism syndrome will not disintegrate in time. This stability-bypothesis was strongly supported in the 1970-1992 period. The second bypothesis suggested that the lev els of authoritarianism bave steadily decreased in time. This decreasing-levels bypothesis also received consistent support. Non authoritarian attitudes are now supported among a majority of the population. It is argued that the decrease of authoritarianism levels cannot be attributed to disintegration of the authoritarianism syndrome proper. Hypothesis three stated that The Netherlands is among the lowest in levels of authoritarianism and state authoritarianism in the world. This lowest level-bypothesis was explored using cross national data of authoritarian attitudes and state authoritarianism. The in dicators indeed suggest that The Netherlands rank among the lowest in authoritarian attitudes as well as in state authoritarianism, together with Scandinavia, Iceland, Canada and New Zealand. The results suggest that the quest of Adormo et al. may have been completed, at least for countries like The Netherlands in the 1990s. 


\section{Introduction}

\section{The research questions}

From the beginning of research on authoritarianism three main issues often were speculated about, but hardly have been investigated. These main issues included the basic questions of (1) whether the authoritarianism syndrome was stable as time went by, whether (2) the levels of authoritarianism would increase or decrease in time, and (3) whether there are high or low authoritarian cultures (or nations).

The authoritarianism syndrome often has been suggested to be rather stable from a psychological point of view, mainly as a matter of assumption. If there was no stability, this syndrome could not be measured, and as a result there would not be a need for investigation. However, this does not seem to be the case after decades of research (Stone, Lederer, Christie 1993, Meloen 1983, 1993, Meloen, Hagendoorn, Raaijmakers, and Visser 1988, Meloen, Van der Linden, and De Witte 1996). The main method to assess stability in psychology is by applying reliability measures. Many authoritarianism scales have been developed that showed adequate and relatively strong reliabilities. This way the stability of authoritarian answers is tested, but not the stability in time. It is suggested that such reactions will be rather stable, but little authoritarianism research involves retesting respondents after a period of time, years or decades. Most contributions to authoritarianism studies were typically so called 'one shot' studies. Only a few were of the retest type.

The first research question, therefore, to be answered is whether there is evidence that the authoritarianism syndrome is stable in can be consideredher the coherence of authoritarian opinions drome of such opinions.
In many studies the level of authoritarianism was measured, but little has been done to find out what such levels mean, or what the differences in levels mean. This leads to the rather opportunistic approach of considering someone, or some group, scoring just a little higher than others to be 'more authoritarian'. However, if all respondents or groups would show low levels of authoritarianism, neither of them could be called 'authoritarian'. This appeared often the case (Meloen 1983). Lack of standards for levels of authoritarianism have obscured much research in this field. An investigation among hundreds of published sample levels showed that differences in (means) levels did seem to have social relevance, and a theoretical model for interpretation was born (Meloen 1983, 1993). Subsequent analyzes have strengthened this model ever since.

The second research question is whether authoritarianism levels have changed in time, increased or decreased. An increase is associated with a higher risk of anti democratic reactions and support for related movements. Since typical authoritarian behavior and reactions tend to be something of the past, an overall decrease in authoritarianism is expected, at least in West Europe. Lederer $(1982,1983)$ showed that such a decrease was possible employing non random high school samples in Germany. Their authoritarianism levels were compared to those of similar groups in 1945 (after Germany's surrender) and the mid sixties. A general decline of authoritarianism levels seems to have some face validity as West Europe became increasingly more democratic and the last dictatorships (Portugal, Spain, a short period in Greece) were dissolved in the seventies.

The third research question concerns the internationally comparative levels of authoritarianism. From the early studies on in the 1950s on in non western cultures, like those of Lebanon (Diab 1959), India, and later in Brazil, Zimbabwe, Hongkong, and (communist) Yugoslavia much higher authoritarianism levels have been encountered, but such results were never analyzed in a com- 
parative international framework (Meloen 1983). They were easily forgotten or discarded as culture related artifacts. However, recent studies have revealed that some of this early work may have had some significance: levels of state authoritarianism and authoritarian of attitudes seemed to be strongly related (Meloen 1996). This supported partially the Fukuyama thesis, of more democracy among those nations with longer democratic traditions (Fukuyama 1992). Fragmented and isolated results from the early authoritarianism studies now do seem to have a relevant meaning. This has been reported elsewhere more in detail (Meloen 1996). We will explore the question, whether the authoritarianism level in The Netherlands is among the lowest in the world and the country can be considered to constitute a non authoritarian society. In that case the mission of Adorno et al. can also be considered to have been completed, at least for this country.

The three hypotheses for this analysis then are as follows:

Hypothesis (1) - The stability bypotbesis: the authoritarianism syndrome will not disintegrate in time.

Hypotbesis (2) - The decreasing levels bypotbesis: the levels of authoritarianism have steadily decreased in time in The Netherlands

Hypothesis (3) - The low level bypothesis: The Netherlands is among the lowest in levels of authoritarianism and state authoritarianism in the world.

\section{The Middendorp Data-Base}

One main methodological fallacy of authoritarianism research was the inadequacy of the - mainly student - samples for generalizing results (Meloen 1983, 1993). Such student samples hardly appeared to be representative of the population as a whole. The majority of psychological investigators based their conclusions on student samples, and hardly bothered finding out whether their results were representative at all. It was shown that most students were much less authoritarian and consistently so, than the population as a whole. Students appeared not to be representative for the general (nation wide) population. The consistent relationship with educational level was a sign that this was to be expected too. Conclusions of much authoritarianism research seem, therefore, now somewhat limited, and at least partially invalid. Large random national samples could have been used for correcting results from student samples. However, such national random samples typically were either absent completely, or F Scales were used that were too short, unreliable, or hardly validated.

Even more rare were repeated random samples using exactly the same methodology and concepts, variables and scales. Not one of these was available in more than fifty years of research on authoritarianism in all the countries known to have contributed to authoritarianism research. There was only one exception: the repeated national random samples $(1970,1975,1980,1985,1992)$ of Middendorp (1978, 1991, Meloen and Middendorp 1991) in The Netherlands. This exceptionally large and consistent database will be analyzed here, with respect to the three mentioned research questions. The first two research questions can only be tested in a database, like the one of Middendorp. He used national random samples of the Dutch population in the ages of 16 to 69 years. A composite database over the five surveys of 1970 , $1975,1980,1985$ and 1992 was constructed, with exactly the same items and variables in every survey. In this way, longitudinal trends became available among the five cross-sectional surveys. A few variables are only available in less than five surveys. These five surveys included more than 9,000 respondents.

The general approach of Middendorp was to construct the values of freedom and equality, and find their meaning in the political attitudes of the population (Middendorp 1978, 1991). Both freedom and equality were operationalized, as were ideologies of 
liberalism, conservatism, socialism and authoritarianism. Two dimensions appeared, one libertarian-conservatism (1978, later on called by Middendorp libertarian-authoritarian, 1991) dimension, including an Adorno et al. short F Scale, and a left-right wing dimension. The libertarian-conservatism dimension included many 'moral' or 'immaterial' political and social issues, while the left-right dimension included mostly 'material' economic issues.

We will not redo this analysis of Middendorp, but only use the concepts related to the Middendorp F Scale. This scale included original Adorno et al. items, covering most of the nine sub syndromes mentioned by Adorno et al. (1950). Since this F Scale loaded highest on the rather extensive libertarian-conservatism dimension, this $F$ syndrome can be considered much wider than the F Scale itself. Therefore, we have taken a number of related concepts and items to construct several authoritarianism scales, according to various theoretical positions of authors, mainly Adorno et al. (1950), and Altemeyer (1988).

This way, various operationalizations of authoritarianism could be tested. Another reason for including more than one operationalization is that after fifty years many different scales have been suggested and used, and much relevant and sometimes less relevant criticisms have been published (Shils 1954 for instance). Therefore, several operationalizations of a similar concept could provide more chances to test this concept and more confidence in the produced results. Most of the analyses were carried out by using the Middendorp F Scale, a widely tested, reliable, and one dimensional scale (Meloen and Middendorp 1991). The Middendorp surveys included a majority of economic issues and government policy items, not analyzed here. Therefore, response set was less likely to occur in the data of the present analysis.

\section{Stability of the Authoritarianism Syndrome}

According to the first hypothesis the authoritarianism syndrome will not disintegrate in time (the stability-hypothesis). First, the reliability and validity coefficients of authoritarianism will be examined. If they appear to be adequate, the hypothesis will be tested by comparing these coefficients in the time period of 1970 to 1992.

\section{Trends Reliability}

To test the reliability of authoritarianism, nine operationalizations of authoritarianism were constructed (scales and items: see appendix). The Middendorp F Scale (7 items: F7 therefore) was included, since this was the scale used by Middendorp, and analyzed earlier (Meloen \& Middendorp 1991). This scale was part of the F10, F16 and F30 versions, that included additional authoritarianism items. The longer $F$ Scales show higher reliabilities (Tables 1 and 3: alpha's of .71 to .87 ), and the longest one even approached the reliability of the original F Scale (1950; then: .90 for 30 items).

Using the same item pool, the three sub syndromes of Altemeyer were operationalized as well, in scales of authoritarian conventionalism, submission and aggression (Tables 2 and 3). The conventionalism scale performed somewhat poorer (alpha of .60), but the other two seemed adequate (alpha's of .73 and .68) for a short scale. The complete Altemeyer operationalization showed even a rather high reliability (18 items: .85$)$. The three sub syndromes also correlated substantially $(.59 \% *$ to $.63 \% *)$, supporting Altemeyer's claim that they do covary, and that they belong to one authoritarianism syndrome.

These results demonstrate that both the Adorno et al. and Altemeyer's concepts reliably can be operationalized on the level of a national random sample. Remarkably, this has never before 
been undertaken. Usually less then ten items were used in such random (national) samples.

Additionally, a scale was constructed, with items that discriminated best between the extreme right wingers and democrats. This scale (REX11) was added was for reasons of exploration, and for optimizing the discriminating performance (an original strategy by Adorno et al.; see Table 3). Its reliability seems adequate (alpha: .76), but its content is theoretically less clear.

A separate analysis (Table 1) showed that the four main F Scale versions are reliable among a number of relevant subgroups as well: between men and women, age groups, class identification, educational levels, religious identification, and willingness to vote. None of the scales collapsed among these social subgroups, although their reliabilities did vary. The short F Scale (7) showed the lowest reliabilities among groups with little education, the lowest social class self rating, and among those unwilling to vote. However, the lowest reliabilities seem to be artifacts of the length of the scale: this effect disappears almost completely for the longer scales. Authoritarianism is even slightly more reliable among the lowest class (.85) then among the highest class (.83) for the longest F Scale. Indeed, the criticism that authoritarianism among the 'working class' does not exist, because scales collapse for such groups, seems unwarranted. Such studies typically used short F Scales, and the lack of reliability can now be attributed to the length of such scales.

We may, therefore, assume that these scales are adequate for our analysis. The short ones will be closer to the original F Scale. The longer ones, with more items, will better represent the $F$ Syndrome as a whole. We will now test whether the F Syndrome collapses in time, or remains stable. If this syndrome had disintegrated in time than it is inevitable that the reliabilities diminish in size as well. We computed the reliabilities for every scale, and separately for each of the five surveys between 1970 and 1992
(Table 3). The results show that there is little indication of lower reliabilities as time passes by, in a period of 22 years.

Table 1. Reliability F Scales and Sub Groups

Alpha Reliability F Scales

\begin{tabular}{|c|c|c|c|c|}
\hline Scales & F7 & F10 & F16 & F30 \\
\hline Number Items & 7 & 10 & 16 & 30 \\
\hline Alpha All Groups & .71 & .77 & .85 & .87 \\
\hline Alpha-30 All Groups & .91 & .91 & .91 & .87 \\
\hline $\begin{array}{l}\text { Men } \\
\text { Women }\end{array}$ & $\begin{array}{l}.71 \\
.71\end{array}$ & $\begin{array}{l}.78 \\
.76\end{array}$ & $\begin{array}{l}.85 \\
.85\end{array}$ & $\begin{array}{l}.87 \\
.86\end{array}$ \\
\hline Young Age & .69 & .77 & .85 & .86 \\
\hline $\begin{array}{l}\text { Middle Age } \\
\text { Old Age }\end{array}$ & $\begin{array}{l}.72 \\
.66\end{array}$ & $\begin{array}{l}.78 \\
.73\end{array}$ & $\begin{array}{l}.85 \\
.81\end{array}$ & $\begin{array}{l}.87 \\
.83\end{array}$ \\
\hline Self Working Class & .67 & .74 & .83 & .85 \\
\hline Self Lower Middle Class & .69 & .74 & .83 & .86 \\
\hline Self Higher Middle Class & .71 & .77 & .84 & .85 \\
\hline Self Upper Class & .71 & .76 & .81 & .83 \\
\hline Primary Education & .62 & .68 & .79 & .83 \\
\hline Secondary Education & .64 & .70 & .80 & .82 \\
\hline Grammar Education & .70 & .76 & .83 & .85 \\
\hline University Education & .72 & .77 & .83 & .85 \\
\hline No Religion & .73 & .79 & .85 & .86 \\
\hline Roman Catholic & .66 & .73 & .82 & .83 \\
\hline Dutch Reformed & .71 & .76 & .83 & .85 \\
\hline Calvinist & .65 & .73 & .83 & .87 \\
\hline Votes & .72 & .78 & .85 & .87 \\
\hline Don't know & .70 & .75 & .82 & .84 \\
\hline Thes not vot & .64 & .74 & .82 & .85 \\
\hline
\end{tabular}

Reliability $=$ Cronbach Alpha; F7: Middendorp F Scale 
Table 2. Reliability and Inter Correlation Altemeyer's Authoritarianism

Scale

Authoritarian Conventionalism

Authoritarian Submission

Authoritarian Aggression

Altemeyer's Authoritarianism

Alpha $=$ Cronbach Alpha $;$ Nit $=$ Number of items; Pearson Correlations Table 3. Trend in Authoritarianism 1970-1992: Reliabilities
F Scales

\begin{tabular}{|c|c|c|c|c|c|c|c|c|c|c|}
\hline $\begin{array}{l}\text { Authoritarianism } \\
\text { Scale }\end{array}$ & Nit & \multicolumn{5}{|c|}{$\begin{array}{l}\text { Alpha Reliabilities } \\
\text { Year of Survey }\end{array}$} & $\begin{array}{l}\text { Alpha } \\
\text { Total } \\
1970 . \\
1992\end{array}$ & Cit & Ntot & Alpha-30 \\
\hline Middendorp F7 & 7 & .70 & .67 & .67 & .72 & .76 & .71 & .26 & 7031 & .91 \\
\hline Adorno F10 & 10 & .77 & .75 & .75 & .76 & .79 & .77 & .25 & 6655 & .91 \\
\hline Adorno F16 & 16 & .84 & .84 & .84 & .83 & .85 & .85 & .27 & 6445 & .91 \\
\hline Adorno F30 & 30 & .86 & .85 & .86 & .83 & - & .87 & .18 & 2493 & .87 \\
\hline Altemeyer CONV6 & 6 & .54 & .56 & .55 & .53 & - & .60 & .20 & 6146 & .88 \\
\hline Altemeyer SUBM6 & 6 & .72 & .72 & .72 & .73 & .75 & .73 & .32 & 7536 & .93 \\
\hline Altemeyer AGR6 & 6 & .68 & .67 & .65 & .67 & .68 & .68 & .28 & 7525 & .91 \\
\hline Altemeyer ALT18 & 18 & .84 & .84 & .84 & .83 & - & .85 & .24 & 4973 & .90 \\
\hline Meloen REX11 & 11 & .76 & .75 & .75 & .76 & .77 & .76 & .23 & 5859 & .90 \\
\hline
\end{tabular}

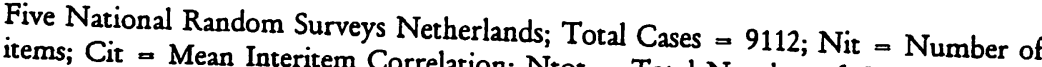
Alpha-30 $=$ Croan Interitem Correlation; Ntot $=$ Total Number of Cases Included F Pa- 30 Cronbach Alpha, if the scale had 30 items of similar cohesion; F7: Middender Ale altemeyer F Scale: CONV +SUBM + AGR; REX = Right Wing Extremism; - = not available due to two missing items in this survey

There is only a slight variation. But by no means is there a decline shown in the strength of the reliabilities. This is true for all the authoritarianism scales in the consecutive surveys of 1970 , $1975,1980,1985$, and 1992. This result firmly supports the stability hypothesis of both the F Scales and the F Syndrome.

\section{Trend Validity}

Scales can be reliable, but not valid. However, there seems to be less agreement on what makes a scale valid, considering the numerous validity indicators that are used. We will distinguish the following main types of validity of the F Scales: discriminant validity, concurrent validity, and explanatory validity. We will also test the trends in time of the various validity coefficients.

\section{Discriminant Validity}

Discriminant validity means that scales discriminate between groups of respondents. Since F Scales are also considered potential fascism scales, to be valid they should discriminate between those who prefer or voted for extreme right wing parties, and those who vote for democratic parties (Meloen, Hagendoorn, Raaijmakers, and Visser 1988, Meloen 1993).

The present F Scales seem to meet this condition: the extreme right shows the highest mean scores (Tables 4 and 5), although not always significantly different from the fundamentalist right (or orthodox Christians). However, fundamentalists may not share many brutal habits of extremists. But they often do share authoritarian and theocratic ideas. The scale, especially constructed from items that discriminated between the extreme right and democrats (REX11), showed highly significant differences. The validity tendencies of these F Scales seem slightly more outspoken in the voting behavior, then in the voting preferences. This would suggest that asking for behavior patterns can be more effective then asking for rather (speculative) intentions. These results support the discriminant validity of the used F Scales. 
Table 4. Authoritarianism and Voting Preference (1970-1992)

\begin{tabular}{|c|c|c|c|c|c|c|c|c|}
\hline \multirow{3}{*}{$\begin{array}{l}\text { Political Parties } \\
\text { Preferred }\end{array}$} & \multirow{2}{*}{\multicolumn{8}{|c|}{$\begin{array}{l}\text { Authoritarianism Scales } \\
\text { F7 }\end{array}$}} \\
\hline & & & & & F16 & & REX11 & \\
\hline & Mean & $\mathbf{N}$ & Mean & $\mathbf{N}$ & Mean & $\mathbf{N}$ & Mean & \\
\hline $\begin{array}{l}\text { Green Left } \\
\text { Social Democrats }\end{array}$ & 3.21 & 501 & 2.88 & 426 & 2.70 & 413 & 2.73 & 401 \\
\hline Liberal Democrats & $\begin{array}{l}4.19 \\
3.67\end{array}$ & 1928 & 3.81 & 1388 & 3.54 & 1355 & 3.59 & 1260 \\
\hline Christian Democrats & $\begin{array}{l}3.67 \\
4.36\end{array}$ & 724 & 3.34 & 577 & 3.11 & 553 & 3.16 & 511 \\
\hline Conservative Democrats & $\begin{array}{l}4.36 \\
4.16\end{array}$ & $\begin{array}{l}2013 \\
1114\end{array}$ & $\begin{array}{l}4.02 \\
3.84\end{array}$ & 1465 & 3.85 & 1408 & 367 & 1320 \\
\hline Fundam Christians & 4.28 & 191 & & 898 & 3.59 & 871 & 3.67 & 791 \\
\hline Right Wing Extremists & $4.85^{*}$ & 41 & $\begin{array}{l}4.42 \\
4.62^{\prime \prime}\end{array}$ & $\begin{array}{r}127 \\
29\end{array}$ & 4.27 & 133 & 374 & 111 \\
\hline Total Populacion & 411 & 6512 & 3.76 & $\begin{array}{r}29 \\
4910\end{array}$ & $\begin{array}{l}4.28^{\prime \prime} \\
3.54\end{array}$ & $\begin{array}{r}29 \\
4460\end{array}$ & $4.46^{*}$ & 28 \\
\hline
\end{tabular}

Few Middendorp F Scale; Range All Scales: 100 Low Aurhoritarian to 700 High Authoritarian; F30 not shown: too (anter Party, Center Democrets

Table 5. Authoritarianism and Voting Behavior (1970-1992)

\begin{tabular}{|c|c|c|c|c|c|c|c|c|}
\hline \multirow{2}{*}{$\begin{array}{l}\text { Political Parties } \\
\text { Voted for }\end{array}$} & \multicolumn{8}{|c|}{ Authoritarianism Scales } \\
\hline & F7 & & & & F16 & & REX11 & \\
\hline Green Left & $\begin{array}{l}\text { Mean } \\
3.30\end{array}$ & $N$ & Mean & $\mathbf{N}$ & Mean & $\mathbf{N}$ & Mean & \\
\hline Social Democrats & $\begin{array}{l}3.30 \\
4.16\end{array}$ & $\begin{array}{r}444 \\
2176\end{array}$ & $\begin{array}{l}2.95 \\
3.77\end{array}$ & 363 & 2.74 & 351 & 2.76 & 339 \\
\hline Liberal Democrats & 3.67 & $\begin{array}{r}2176 \\
610\end{array}$ & 3.77 & 1576 & 3.52 & 1543 & 3.57 & 1417 \\
\hline Christian Democrats & 4.36 & 2181 & $\begin{array}{l}3.32 \\
4.01\end{array}$ & $\begin{array}{r}488 \\
593\end{array}$ & 3.07 & 469 & 3.14 & 420 \\
\hline Conservative Liberals & 4.18 & 1136 & $\begin{array}{l}4.01 \\
3.84\end{array}$ & $\begin{array}{r}1593 \\
909\end{array}$ & $\begin{array}{l}3.83 \\
3.58\end{array}$ & 1530 & 3.66 & 1409 \\
\hline Fundam Christians & 4.28 & 190 & 4.39 & 132 & 3.58 & 880 & 3.67 & 812 \\
\hline Right Wing Extremists & $5.08^{*}$ & 42 & $4.72^{\star 4}$ & 32 & $\begin{array}{l}4.22 \\
4.39 \%\end{array}$ & $\begin{array}{r}138 \\
30\end{array}$ & 3.72 & 115 \\
\hline Total Popularion & 414 & 6779 & 378 & 5093 & & & $4.41^{*}$ & \\
\hline & & & & 5093 & 355 & 4941 & 352 & \\
\hline
\end{tabular}

F7: Middendorp F Scale; Range All Scales: 100 Low Aurhorite 700 Hifh A

30 not shown: too

few cases left for target group extremists; Right Wing Extremists: Fa 700 High Authoritarian; F30 not shown: too

The number of right wing extremists was too small in the separate surveys. Therefore, a trend in this type of validity could not be computed.

\section{Concurrent Validity}

Concurrent validity applies to correlations between authoritarianism and external variables, within the same survey. Positive correlations between F Scales and anti feminism authoritarian parental attitudes, authoritarian attitudes toward children, anti homosexual attitudes, anti freedom attitudes, anti democratic attitudes, nationalism and anomia, all can be considered to support the concurrent validity of the used F Scales. All the correlations between authoritarianism and external variables 56 shown here (Table 6) are significant and a number is quite substantial, although elsewhere sometimes higher correlations have been reported. The longer $\mathrm{F}$ scales also show somewhat higher correlations here (there is no item overlap between the external scales) as can be expected from their higher reliabilities. The results here support the concurrent validity of the F Scales.

Table 6. Authoritarianism and External Variables: Trend in Correlations 1970-1992

\begin{tabular}{|c|c|c|c|c|c|c|}
\hline & Nit & Alpha & F7 & F10 & F16 & F30 \\
\hline Nit & & & 7 & 10 & 16 & 30 \\
\hline Alpha & & & .71 & .77 & .85 & .87 \\
\hline Anti Freedom Attitudes & 7 & .75 & $.31^{3 * 24}$ & $.39 \div 2 *$ & $.44 * 5 * 3$ & $.53^{2 * 3 *}$ \\
\hline Anti Democratic Attitudes & 3 & .80 & $.13 * * \%$ & $.18^{2 * 6 * 3}$ & $.20 \% 3$ & $.26 * 254$ \\
\hline Nationalism & 4 & .73 & $.47 \div \div \%$ & $.54^{2 * 2 * 8}$ & $.57 \%$ & $.61^{2+28}$ \\
\hline Anomia & 5 & .77 & $.58^{* 2 * 3 *}$ & $.59^{2 \times 3+2 *}$ & $.54 \div 2+4$ & $.48 * 2 \%$ \\
\hline Nmin & & & 4638 & 3477 & 3394 & 1627 \\
\hline $\operatorname{ngx}$ & & & 9112 & 6655 & 6445 & 2493 \\
\hline
\end{tabular}

F7: Middendorp F Scale; Pearson Correlations; **** $=\mathrm{p}<.001 ; * *=.001<\mathrm{p}<.01$; ${ }^{*}=$ $.01<p<.05$; Nit: Number of items; Nmin/Nmax: Minimum/Maximum Number of Respondents; there is no overlap in items between the external variables and with the $F$ scales

We can now assess whether the external validity of $F$ Scales will collapse in time or remain stable. In case of collapse the external correlations will become lower and insignificant in time. This appears not to be the case (Table 7) in most instances. The F Scales correlate survey after survey at a stable level, and as expected with anti feminism, authoritarian parental attitudes, authoritarian attitudes toward children, anti homosexual attitudes, anti freedom attitudes, anti democratic attitudes, nationalism and anomia, and also with the general conservatism-libertarianism dimension of Middendorp (with conservatism therefore), but hardly, and stable so with the socioeconomic left-right wing dimension of Middendorp.

Also, there seems to be a slight decrease in the correlations until 1985 for some variables, but this is compensated by higher corre- 
lations in the last survey of 1992 . Over all, there may be some variation, but the main impression is one of great stability. Only the results for the F7 Scale are presented, but the pattern is roughly similar for the other F Scales. The longer F Scales also show somewhat higher correlations in this respect.

Table 7. Authoritarianism and External Variables: Trend in Correlations 1970-1992

\begin{tabular}{|c|c|c|c|c|c|c|c|c|}
\hline $\begin{array}{l}\text { Authoritarianism } \\
\text { (F Scale F7) and: }\end{array}$ & Nit & Alpha & 1970 & 1975 & 1980 & 1985 & 1992 & Total \\
\hline Anti feminism & 4 & .73 & $.49+174$ & $.45^{m m n}$ & $.44^{74+4}$ & $.41^{\#+4 \pi}$ & .43 & $.47^{* * *}$ \\
\hline Parental Attitudes & & .75 & & $.52^{\text {nat4 }}$ & $.51^{1044}$ & $.49^{4+48}$ & $.51^{1744}$ & $.53 * * *$ \\
\hline Attitudes to Child & 6 & 55 & $.34^{4 m, 4}$ & $.29+404$ & $.34^{4+4 n+4}$ & $.294+4$ & & $35^{* * *}$ \\
\hline itudes & & 76 & $.33^{3+44}$ & $.32^{\text {nnd }}$ & $.23^{3+44}$ & $.20^{3+4}$ & $.24+474$ & $.30^{* * *}$ \\
\hline & & 75 & .29:40 & 3044 & $33^{3 \mathrm{na}}$ & $30^{404}$ & .28740 & $31^{* * * *}$ \\
\hline & & & $.23^{3404}$ & $.16^{404}$ & $.24^{* 44}$ & $.16^{* 04}$ & $.02 \mathrm{~ns}$ & $13 * * *$ \\
\hline Jationalism & & 73 & $.53^{\text {thon }}$ & $.47^{n+m}$ & $.49^{\text {mmm }}$ & $.47^{m+34}$ & .43 & $.47^{* * * *}$ \\
\hline & 5 & 77 & $.58^{\text {now }}$ & $.52^{3+14}$ & $.52^{4+144}$ & $.56 \% 1+4$ & $.65^{5+4 \times 4}$ & $.58 * * *$ \\
\hline $\min$ & & & 1255 & 893 & 927 & 1090 & 1170 & 4165 \\
\hline $\max$ & & & 1783 & 1683 & 1666 & 1700 & 1623 & 8400 \\
\hline 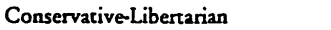 & 9 & & $.53^{\mathrm{nhm}}$ & & & & & $52^{* * *}$ \\
\hline eft-Right Economic Cons & 9 & & $.00 \mathrm{~ns}$ & $.00 \mathrm{~ns}$ & $.05^{*}$ & $.02 \mathrm{~ns}$ & $.19^{4+44}$ & $.07 * * *$ \\
\hline & & & & & & & & \\
\hline
\end{tabular}

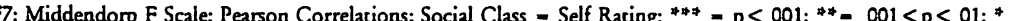
$01<p<05$; ns - non significant; there is no overlap in items between the presented scales

Again there is little indication of collapse of the authoritarianism scales or syndrome, instead there seems to be quite some stability. The results seem to suggest strong support for the concurrent validity of the used $\mathrm{F}$ Scales in time.

\section{Explanatory Validity}

Although not very commonly used, this type of validity can be considered to be related to social background variables like sex and age, educational level, and social class. Stable relations with these variables indicate stable explanations on a social level. Indeed, the most reported background variable related to F Scales is educational level, but also age and social class have been associated with explanations of authoritarianism.

The results show (Table 8) that there is no relation with being male or female, and this lack of relation is rather stable in time, 58 even though in 1970 females tended to score slightly higher. The difference has become insignificant since (see below). Most remarkable is that age, educational level, educational level of the father and social class show quite a stable relation with the $F$ Scales in time. On a national random sample level there hardly seems to be a trend up or downward at all. This is also the case for the other F Scales (not shown here).

From these results we can again only conclude that stability in the relations with the social variables is the over all impression. It supports the explanatory validity of the used F Scales, and therefore the stability-hypothesis.

Table 8. Authoritarianism and Social Variables: Trend in Correlations 1970-1992

\begin{tabular}{|c|c|c|c|c|c|c|}
\hline F Scale (F7) and: & 1970 & 1975 & 1980 & $\begin{array}{l}1985 \\
.01\end{array}$ & $\begin{array}{l}1992 \\
-.02\end{array}$ & $\begin{array}{l}\text { Total } \\
-.002\end{array}$ \\
\hline Male/Female & $.06^{*}$ & .02 & $\begin{array}{l}.03 \\
.28^{\text {ntwat }}\end{array}$ & .01 & $.27^{+4+4}$ & $.26 * * *$ \\
\hline &. $.41^{+* * 4}$ &. $.38^{-6 \times 4}$ & $-.37^{7+104}$ & $.39 * 4 \$$ &. $.44^{4+4}$ & $-41^{* * *}$ \\
\hline $\begin{array}{l}\text { Education } \\
\text { Education Father }\end{array}$ & $-.27^{4 * \infty}$ &. $.26^{* * 44}$ & $-27^{+4+\infty}$ & $-.30^{* 340}$ & & $.28^{* * *}$ \\
\hline $\begin{array}{l}\text { Education Father } \\
\text { Social Class }\end{array}$ & $.28^{\text {th+n }}$ & $-.26^{* * 4}$ & $.20^{4 * 4 * 4}$ & $.18^{4 / 44}$ & $.32^{4,4 n}$ & $-.26^{* * *}$ \\
\hline Town Size Youth & $.12^{* * *}$ & $.11^{* * * *}$ & $.07^{* *}$ & $.05^{*}$ & $08^{* *}$ & -002 \\
\hline Size Community & $\mathrm{x}$ & $-09^{*+4 *}$ & .01 & & & \\
\hline
\end{tabular}

F7: Middendorp F Scale; Pearson Correlations; Social Class - Self Rating; ** $-p<001$; **- $001<p<.01$; * $01<\mathrm{p}<05$

\section{Conclusion Stability Hypothesis}

The authoritarianism syndrome will not disintegrate in time. This hypothesis was strongly supported. It was tested by comparing the reliabilities of authoritarianism operationalizations in time, by comparing main validity coefficients in time, and by comparing the relation with social variables in time. The reliabilities of the nine authoritarianism scales did not decrease in time, but showed considerable stability.

Some of the main validity coefficients (Anti feminism, authoritarian parental attitudes, authoritarian attitudes toward children, anti homosexual attitudes, nationalism, anti freedom attitudes, 
anti democratic attitudes, anomia) also did not show any weakening in time, and finally the social variables (male/female, education, education of the father, age, self rating of social class) mainly showed stable relationships in time. This was the case for the short Middendorp F Scale, as well as for the wider F Syndrome.

It was concluded that there does not seem to be any sign of weakening of the authoritarianism syndrome: a syndrome of related authoritarian attitudes and opinions. This is rather remarkable, considering also the next hypothesis.

\section{Change in Authoritarianism Levels}

Now that it is shown that the authoritarianism syndrome has not disintegrated in time and the instruments show considerable validity, we can assess the changes in authoritarianism levels (mean scores) over a time period of 22 years. We will show this for the over all trend, as well as for various relevant subgroups and social categories. According to the second hypothesis we expect a decrease in authoritarianism from 1970 on.

\section{Trend in General Authoritarianism Levels}

The results (Table 9) show indeed that the general trend is one of decreasing levels of authoritarianism, ever since the first survey of 1970 . This trend is almost linear as in every following survey year the means are lower, than in the former survey. There is no instance of a temporary rise in authoritarianism levels. This is also the case for every one of the F Scales shown.

This very consistent downward trend is again quite remarkable. In the early 1980s there was an economic crisis in The Netherlands, like in many other countries at the time. However, no immediate increase in authoritarianism has been registered here. But right wing extremist activities did increase in this period.
This may support the thesis that not the attitudes change in an economic crisis, but the attitude-behavior relation among authoritarian extremists: they will act more consistent with their authoritarian attitudes in such crises. Unfortunately, we cannot test this thesis here, mainly due to the low numbers of such extremists in our database.

The trend is consistent with the results of Lederer $(1982,1983)$ in Germany. Meloen (1983) also found a decrease during the 1960s in the USA among students, while Altemeyer found an increase since the mid 1970s among Canadian students (1988). Therefore, the authoritarianism levels may fluctuate in time somewhat, although not dramatically. It also suggests that the trend in North America may not be similar to the one in West Europe, if these results could be generalized. We lack enough studies to do so at the moment, but the few available studies may suggest this.

Table 9. Trend in Authoritarianism 1970-1992: Mean F Scores

\begin{tabular}{lccllllll} 
Authoritarianism & \multicolumn{2}{c}{ Year of Survey } & & & \multicolumn{4}{c}{ Total 1970-1992 } \\
Scale & 1970 & 1975 & 1980 & 1985 & 1992 & Mean & Sd & N \\
Middendorp F7 & 4.48 & 4.33 & 4.10 & 4.01 & 3.83 & 4.15 & 1.21 & 9112 \\
Meloen F10 & 4.07 & 3.99 & 3.74 & 3.66 & 3.50 & 3.80 & 1.07 & 6655 \\
Meloen F16 & 3.93 & 3.77 & 3.50 & 3.38 & 3.22 & 357 & 097 & 6445 \\
Meloen F30 & 3.67 & 3.32 & 3.05 & 2.99 & - & 327 & 082 & 2493 \\
Altemeyer CONV6 & 4.25 & 3.85 & 3.40 & 3.30 & - & 3.72 & 1.08 & 6146 \\
Altemeyer SUBM6 & 4.78 & 4.71 & 4.55 & 4.33 & 4.19 & 452 & 1.15 & 7536 \\
Altemeyer AGR6 & 3.07 & 2.93 & 2.57 & 2.47 & 2.44 & 270 & 108 & 7525 \\
Meloen REX11 & 3.82 & 3.77 & 3.47 & 3.43 & 3.26 & 3.56 & 0.99 & 5859
\end{tabular}

Five National Random Surveys Necherlands; Total Cases - 9112; F7: Middendorp F-Scale; for all F Scales: differences between groups significant, as well as linearity, by means of ANOVA ( $<<0001)$; - - not available due to two missing items in the 1992 surver

\section{Trend in Levels for Men and Women}

The trend for men and women is similar to the general authoritarianism trend. Both men and women show lower levels in time. However, an additional trend is that men and women seem to have become more equal in their authoritarianism levels. The differences have become somewhat smaller, and are not significantly different since 1970 . In the 1970 survey women still 
showed slightly higher levels than men, as was the case in many older studies. This was interpreted as women to be more submissive (toward men) in general. Since the general trend here is in the direction away from authoritarianism, a new interpretation can be that women now are less different in this respect from men. This seems to be the case for the society as a whole as well, as in the last decades feminist activities have lead to greater (although not complete) equality in social roles of women compared to men.

Table 10. Trend in Authoritarianism 1970-1992: Mean F Scores of Men and Women

\begin{tabular}{|c|c|c|c|c|c|c|}
\hline & \multicolumn{5}{|c|}{ Year of Survey } & \multirow{2}{*}{$\begin{array}{l}\text { Total } \\
1970-1992\end{array}$} \\
\hline & 1970 & 1975 & 1980 & 1985 & 1992 & \\
\hline Men & 4.41 & 4.31 & 4.14 & 4.02 & 3.86 & 4.16 \\
\hline Women & 4.54 & 4.35 & 4.07 & 4.00 & 3.80 & 4.15 \\
\hline Total Population & 4.47 & 4.33 & 4.10 & 4.01 & 3.83 & 4.15 \\
\hline $\mathrm{N}$ & 1903 & 1789 & 1859 & 1791 & 1754 & 9096 \\
\hline
\end{tabular}

Middendorp F Scale F7; Range: 1.00 Low Authoritarian to 7.00 High Authoritarian

\section{Trend in Levels for Age Groups}

The decline of authoritarianism levels is also visible in the age groups (Table 11). In general, the older groups have shown higher levels than the younger ones, with the exception of the youngest groups. Earlier birth cohort analysis with the same surveys showed that this is not due to higher levels within the same birth cohorts in time: one does not become more authoritarian when one gets older (Meloen and Middendorp 1991). Actually a slight, but rather consistent downward trend can also be shown for most of the birth cohorts (diagonals top-left to bottom-right in table 11). They represent the same groups, born in the same time period and upon close inspection one can see that their levels tend to decrease in time.

In cross sectional analysis the youngest groups (17-19 year) seem an exception. Their levels are almost consistently somewhat 62 higher than the next, older group (20-24 year), and this rise is more outspoken in the later surveys. One explanation could be that these young people are much influenced still by their par ents at the ages of 17 to 19 years, but less so when they become older and independent. At the same time their par 40 to 50 , and in every surtwenty to thirty years older (ages of 40 to 50 ), and in than their vey (Table 11) show higher levels of authoritarianismerefore mean youngsters. Getting away from their parents courly twenties. The same a tendency toward lower levels in their parents and their grand parents.

Table 11. Trend in Authoritarianism 1970-1992: Mean F Scores of Age Cohorts

$\begin{array}{llllll}\text { Age Group } & 1970 & 1975 & 1980 & 1985 & 1992 \\ \text { 17-19 Year } & 4.10 & 3.96 & 3.79 & 3.60 & 3.67 \\ \text { 20-24 Year } & 4.08 & 3.80 & 3.67 & 3.62 & 3.50 \\ \text { 25-29 Year } & 4.16 & 4.00 & 3.75 & 3.64 & 3.44 \\ \text { 30-34 Year } & 4.32 & 4.19 & 3.98 & 3.82 & 3.48 \\ \text { 35-39 Year } & 4.62 & 4.39 & 3.93 & 4.02 & 3.66 \\ \text { 40-44 Year } & 4.52 & 4.50 & 4.24 & 4.03 & 3.75 \\ \text { 45-49 Year } & 4.61 & 4.51 & 4.29 & 4.16 & 3.92 \\ \text { 50-54 Year } & 4.68 & 4.56 & 4.41 & 4.47 & 4.29 \\ \text { 55-59 Year } & 4.83 & 4.61 & 4.53 & 4.39 & 4.42 \\ \text { 60-64 Year } & 5.05 & 4.81 & 4.46 & 4.59 & 4.53 \\ \text { 65-69 Year } & 5.08 & 4.73 & 4.75 & 4.51 & 4.57 \\ & & & & & \\ \text { Total Population } & 4.48 & 4.33 & 4.10 & 4.01 & 3.83 \\ \text { N } & 1905 & 1803 & 1859 & 1791 & 1754\end{array}$

Middendorp F Scale F7; Range: 1.00 Low Authoritarian to 7.00 High Authoritarian

\section{Trend in Levels for Educational Groups}

The general decrease in authoritarianism is shown (Table 12) for the various educational levels, most outspoken in the levels of those with secondary school education and higher. There seems the decrease for the lowest educational levels. These groups showed a decrease over the 1970s, but this is 
less the case in the 1980s, and there may even be a slight rise in the 1990s. However, this does not seem to alter the general trend for the educational levels.

A similar trend is shown for the educational levels of the father of the respondent (Table 13, in 1992 survey not available). In general, the decrease is visible here too, although less outspoken. This time, the trend is less clear for the secondary and highest educational levels. Since this question was less well answered (about one third apparently did not know their father's education), the respondent's educational level seems a better indicator for our analysis here.

Table 12. Trend in Authoritarianism 1970-1992: Mean F Scores of Educational Level

$\begin{array}{llllllc} & 1970 & 1975 & 1980 & 1985 & 1992 & \text { Total 1970-1992 } \\ \text { Primary School } & 4.91 & 4.67 & 4.49 & 4.49 & 4.55 & 4.64 \\ \text { Secondary School } & 4.37 & 4.23 & 4.00 & 3.96 & 3.77 & 4.06 \\ \text { Grammar School } & 3.79 & 3.70 & 3.58 & 3.47 & 3.20 & 3.53 \\ \text { University } & 3.46 & 3.30 & 3.22 & 3.11 & 2.98 & 3.18 \\ \text { Total Population } & 4.47 & 4.33 & 4.10 & 4.01 & 3.83 & 4.15 \\ \text { N } & 1868 & 1796 & 1853 & 1784 & 1732 & 9033\end{array}$

Middendorp F Scale F7; Range: 1.00 Low Authoritarian to 7.00 High Authoritarian

Table 13. Trend in Authoritarianism 1970-1992: Mean F Scores of Educational Level Father

$\begin{array}{lllllc} & 1970 & 1975 & 1980 & 1985 & \text { Total 1970-1985 } \\ \text { Primary School } & 4.74 & 4.51 & 4.34 & 4.28 & \\ \text { Secondary School } & 4.22 & 4.04 & 3.46 & 3.72 & 4.49 \\ \text { Grammar School } & 4.03 & 3.85 & 3.71 & 3.47 & 3.90 \\ \text { University } & 3.74 & 3.35 & 3.19 & 3.17 & 3.74 \\ \text { Total Population } & 4.55 & 4.37 & 4.15 & 4.03 & 3.42 \\ \text { N } & 1315 & 1299 & 632 & 1392 & 4.29 \\ & & & & & 4638\end{array}$

Middendorp F Scale F7; Range: 1.00 Low Authoritarian to 7.00 High Authoritarian;
1992: not available

\section{Trend in Levels for Social Class Groups}

The various social classes (by self rating) show again (Table 14) a similar decrease of authoritarianism in time, most consistent in the middle class groups. Both working class and upper class show a less consistent pattern.

The results for the occupational groups support this general decrease in time too (Table 15), but there are exceptions to this trend among the various occupational groups themselves. An explanation is not clear. The differences between groups do show some consistency, as was reported before (Meloen and Middendorp 1991). Low levels can be found among the free professions and the higher and mid level employees, and relatively high authoritarianism levels among the groups of unskilled laborers, farmers, and fishermen. Remarkably, directors tend to show levels in between these groups.

Table 14. Trend in Authoritarianism 1970-1992: Mean F Scores of Social Class (Self Rating)

$\begin{array}{lcccccc} & 1970 & 1975 & 1980 & 1985 & 1992 & \text { Total 1970-1992 } \\ \text { Working Class } & 4.95 & 4.68 & 4.41 & 4.34 & 4.38 & 4.56 \\ \text { Lower Middle Class } & 4.54 & 4.35 & 4.16 & 4.09 & 4.03 & 4.24 \\ \text { Upper Middle Class } & 4.16 & 3.95 & 3.86 & 3.76 & 3.39 & 3.81 \\ \text { Upper Class } & 3.62 & 3.77 & 3.61 & 3.82 & 3.06 & 3.57 \\ \text { Total Population } & 4.50 & 4.34 & 4.11 & 4.04 & 3.83 & 4.17 \\ \text { N } & 1661 & 1671 & 1744 & 1648 & 1610 & 8334\end{array}$

Middendorp F Scale F7; Range: 1.00 Low Authoritarian to 7.00 High Authoritarian 
Table 15. Trend in Authoritarianism 1970-1992: Mean F Scores of Occupational Levels

\begin{tabular}{|c|c|c|c|c|c|}
\hline & 1975 & 1980 & 1985 & 1992 & Total 1970-1992 \\
\hline Director > 10 Employees & 4.73 & 3.94 & 3.92 & 3.74 & 4.07 \\
\hline Director < 10 employees & 4.62 & 4.22 & 4.32 & 3.98 & 4.34 \\
\hline Professionals & 3.27 & 3.58 & 3.67 & 2.06 & 3.11 \\
\hline Farmers-Fishermen & 4.93 & 4.65 & 4.23 & 4.44 & 4.54 \\
\hline High Level Employees & 3.72 & 3.76 & 3.21 & 3.05 & 3.37 \\
\hline Mid Level Employees & 3.99 & 3.76 & 3.81 & 3.41 & 3.73 \\
\hline Low Level Employees & 4.31 & 4.16 & 4.24 & 4.13 & 4.20 \\
\hline Skilled Labor & 4.48 & 4.38 & 4.34 & 4.36 & 4.40 \\
\hline Unskilled Labor & 4.91 & 4.62 & 4.75 & 4.64 & 4.74 \\
\hline Total Population & 4.34 & 4.13 & 4.03 & 3.85 & 4.09 \\
\hline $\mathrm{N}$ & 1405 & 1366 & 1335 & 1436 & 5542 \\
\hline
\end{tabular}

Middendorp F Scale F7; Range: 1.00 Low Authoritarian to 7.00 High Authoritarian

\section{Trend in Levels for Religious Identification}

In The Netherlands the main religious groups are the Protestants (Calvinists, Dutch reformed) and Catholics. The Protestants dominated the Netherlands from the time of its independence in the $17^{\text {th }}$ century, and lived north of the Rhine, the Catholics mainly south of this river. The trends in authoritarianism for the religious groups are both in general and for specific religious groups almost similar, and downward in time (Table 16). This is consistent with the ongoing secularization of the Dutch population, both Protestant and Catholic. Only among the Dutch reformed the trend is less outspoken.

Table 16. Trend in Authoritarianism 1970-1992: Mean F Scores Religious Members

$\begin{array}{llllllc} & 1970 & 1975 & 1980 & 1985 & 1992 & \text { Total 1970-1992 } \\ \text { Not member } & 4.35 & 4.08 & 4.04 & 3.84 & 3.68 & 3.97 \\ \text { Roman Catholic } & 4.63 & 4.63 & 4.27 & 4.24 & 4.24 & 4.43 \\ \text { Dutch reformed } & 4.49 & 4.50 & 4.09 & 4.17 & 3.86 & 4.26 \\ \text { Calvinist } & 4.47 & 4.27 & 4.02 & 4.03 & 3.75 & 4.13 \\ \text { Population } & 4.48 & 4.33 & 4.10 & 4.00 & 3.83 & 4.15 \\ \text { N } & 1799 & 1739 & 1796 & 1741 & 1682 & 8757\end{array}$

Middendorp F Scale F7; Range: 1.00 Low Authoritarian to 7.00 High Authoritarian 66

\section{Trend in Levels for Regions}

The general regional trend for the eleven provinces is similar to the general trend for the country as a whole (Table 17). Since the differences in authoritarianism between provinces are rather small, the trend is not always very consistent as time passed by. The higher levels of Limburg, Zeeland and Friesland (relative orthodox and rural regions) remain relatively high, while the lowest, Holland, Utrecht, Groningen and Gelderland remain low. These provinces are more advanced, urban, liberal and less orthodox in a religious sense.

Considering the size of the community where the respondents live, the downward trend is only visible in the general results in time, but less so for the most populated (largest cities) and least populated communities (smallest villages). The regional differences in authoritarianism are not expected to be very impressive in The Netherlands. This is because the country has been for a long time the most densely populated of the (post)industrial world. After World War II it was completely modernized, heavily industrialized and urbanized, and differences between cities and rural areas are ever decreasing, now with less than 5 percent of the population in farming. Regional differences therefore seem to have lost their traditional meaning, although some remaining differences in authoritarianism might be related to surviving regional traditions. 
Table 17. Trend in Authoritarianism 1970-1992: Mean F Scores of Provinces

$\begin{array}{llllllc}\text { Groningen } & 1970 & 1975 & 1980 & 1985 & 1992 & \text { Total 1975-1992 } \\ \text { Friesland } & 4.42 & 4.27 & 4.02 & 3.76 & 3.87 & 3.99 \\ \text { Drenthe } & 4.29 & 4.59 & 4.16 & 4.32 & 3.83 & 4.23 \\ \text { Overijssel } & 4.25 & 4.28 & 4.01 & 4.08 & 4.05 & 4.10 \\ \text { Gelderland } & 4.49 & 4.28 & 4.12 & 4.24 & 3.84 & 4.11 \\ \text { Utrecht } & 4.47 & 4.32 & 3.95 & 3.94 & 3.75 & 4.00 \\ \text { North Holland } & 4.42 & 4.13 & 4.18 & 3.93 & 3.63 & 3.94 \\ \text { South Holland } & 4.24 & 4.04 & 3.96 & 3.86 & 3.71 & 3.89 \\ \text { Zeeland } & 4.42 & 4.31 & 4.15 & 3.92 & 3.86 & 4.07 \\ \text { North Brabant } & 4.54 & 4.64 & 4.05 & 4.26 & 3.91 & 4.23 \\ \text { Limburg } & 4.57 & 4.39 & 4.23 & 4.05 & 3.79 & 4.11 \\ \text { Total Population } & 4.56 & 4.80 & 4.26 & 4.32 & 4.14 & 4.39 \\ \text { N } & 4.41 & 4.33 & 4.11 & 4.01 & 3.83 & 4.07 \\ & 1925 & 1799 & 1859 & 1791 & 1754 & 7203\end{array}$

Middendorp F Scale F7; Range: 1.00 Low Authoritarian to 7.00 High Authoritarian

Table 18. Trend in Authoritarianism 1970-1992: Mean F Scores of Size Municipality

\begin{tabular}{|c|c|c|c|c|c|}
\hline & 1975 & 1980 & 1985 & 1992 & Total 1975-1992 \\
\hline $\begin{array}{l}>400.000 \text { inhabitant } \\
100.000-400.000\end{array}$ & 4.20 & 4.12 & 3.83 & 3.87 & 4.02 \\
\hline $\begin{array}{l}100.000-400.000 \\
50.000-100.000\end{array}$ & 4.26 & 4.02 & 3.82 & 3.59 & 3.94 \\
\hline $20.000-50.000$ & 4.26 & 4.19 & 4.00 & 3.74 & 4.03 \\
\hline $10.000-20.000$ & 4.35 & 4.07 & 4.05 & 3.85 & 4.06 \\
\hline $5.000-10.000$ & $\begin{array}{l}4.41 \\
4.47\end{array}$ & 4.07 & 4.25 & 4.00 & 4.18 \\
\hline$<5.000$ & $\begin{array}{l}4.47 \\
4.56\end{array}$ & 4.26 & 3.92 & 3.79 & 4.12 \\
\hline Total Population & $\begin{array}{l}4.56 \\
4.33\end{array}$ & 3.98 & 4.32 & 4.24 & 4.29 \\
\hline- & $\begin{array}{l}4.33 \\
1798\end{array}$ & $\begin{array}{l}4.10 \\
1859\end{array}$ & $\begin{array}{l}4.01 \\
1701\end{array}$ & 3.83 & 4.07 \\
\hline & & 1859 & $1 / 91$ & 1754 & 7202 \\
\hline
\end{tabular}

Middendorp F Scale F7; Range: 1.00 Low Authoritarian to 7.00 High Authoritarian

\section{Conclusions Decreasing Levels Hypothesis}

The authoritarianism levels have steadily decreased in time, between 1970 and 1992. The second hypothesis was again strongly supported by the presented results. This hypothesis was tested by comparing the authoritarianism levels (F Scale means) in time.
Contrary to other social and political issues in The Netherlands, and contrary to such levels in other countries, like the USA, the levels of the various operationalizations of authoritarianism have all decreased since the first survey of 1970 , in a rather linear consistent way. Since the mid eighties all these levels have moved also to the non authoritarian side, providing evidence that non authoritarian attitudes and values are now supported among a majority of the population. The age cohorts may provide some indication that this trend will hardly change in the near future. Only a small rise was noted among the youngest age groups.

Considering the stark support for the stability hypothesis of the F syndrome, it is argued that the decrease of authoritarianism levels cannot be attributed to disintegration of the authoritarianism syndrome proper, the 'tainting' or 'wearing out' of the used items or scales. Therefore, this hypothesis (2) is well supported in the period covered by the surveys.

\section{Secularization, Education and Authoritarianism}

The decline of authoritarianism levels in The Netherlands is quite clear, but why this is so, is still rather obscure. Indeed, it is not clear, what the longitudinal influences are. There seem to be more hypotheses in this field, than tested theories (Meloen 1983). To shed some more light on this very important issue, we will analyze some of our longitudinal data.

According to Middendorp $(1978,1991)$ the secularization in The Netherlands played a major role in the support for political parties, especially the Christian Democrats and their predecessors. The powerful position of the Christian Democrats (Christian parties ruling the country in coalitions for over a century) has deteriorated especially since the late 1960s. 


\section{Table 19. Secularization in The Netherlands}

$\begin{array}{llll} & \begin{array}{l}\text { Raised } \\ \text { Religious }\end{array} & \begin{array}{l}\text { Membership } \\ \text { Religion }\end{array} & \begin{array}{l}\text { Cburch } \\ \text { Attendance }\end{array} \\ 1970 & 1.77 & 1.59 & 3.78 \\ 1975 & 1.74 & 1.55 & 3.38 \\ 1980 & 1.73 & 1.48 & 3.34 \\ 1985 & 1.70 & 1.45 & 2.10 \\ 1992 & 1.70 & 1.40 & 1.93 \\ \mathrm{~N} & 8616 & 8757 & 6611\end{array}$

differences between groups are significant by ANOVA; Church Attendance = 5 categories, low (1) is 'never', high (5) is 'often'; for Membership Religion and Raised Religious = 2 categories: low (1) is 'no', high (2) is 'yes'

However, it took several decades, until 1994 before the first government without Christian Democrats emerged. Secularization has been a main factor here. In the past decades a considerable decrease of religious identification (membership) and activities (church attendance) were reported, and this is also reflected in our present data set of the Middendorp surveys.

To understand a possible relation between this process of secularization and the decreasing levels of authoritarianism, an additional analysis was needed. Time series analysis was not possible, since we have only five measurement points in time (time series analysis requires at least 30 points in time). Therefore, we had to resort to a combination of cross sectional and limited longitudi$\mathrm{nal}$ analysis. The intention was to find (relevant) factors that would be related to authoritarianism both cross sectionally and longitudinally. The factors that would only be associated in cross sections might not be related to longitudinal trends, and vice versa.
Table 20. Longitudinal Trend 1970-1992

$\begin{array}{lll}\text { Variable } & \text { Significance } & \text { Direction } \\ \begin{array}{c}\text { Authoritarianism } \\ \text { F7 F Scale }\end{array} & \mathrm{p}=.001 & \text { decrease } \\ \text { F10 } & \mathrm{p}=.004 & \text { decrease } \\ \text { F16 } & \mathrm{p}=.002 & \text { decrease } \\ \text { REX11 } & \mathrm{p}=.007 & \text { decrease } \\ \text { AGR6 } & \mathrm{p}=.022 & \text { decrease } \\ \text { SUBM6 } & \mathrm{p}=.002 & \text { decrease } \\ \text { Related Variables } & & \\ \text { Education } & \mathrm{p}=.038 & \\ \text { Religious Membership } & \mathrm{p}=.001 & \text { increase } \\ \text { Church Attendance } & \mathrm{p}=.017 & \text { decrease } \\ \text { Secularization } & \mathrm{p}=.013 & \text { decrease } \\ & & \text { increase } \\ \text { Control Variables } & & \\ \text { Age } & \mathrm{p}=.81 & \text { not significant } \\ \text { Social Class } & \mathrm{p}=.17 & \text { not significant }\end{array}$

Pearson correlations between five years of survey and variable; secularization Pearson correlations be religious membership and church attendance; control variables should not change in time (non significance)

The cross sectional relations have been reported above. After extensive analysis the only relevant variables significant in both cross-sectional and longitudinal ways, and relevant to authoritarianism theories were the following: religious identification (combination of membership and church attendance) and levels of education. These two were the only factors in the present surveys that met our criteria.

The significance of the level of education is rather surprising, since it is a main social variable, if not the most important social variable of authoritarianism (Simpson 1972, Duckitt 1992, Meloen and Middendorp 1991). In the past decades the level of education has been rising slowly but steadily. As a result older generations received less education than the younger ones that replace them. Since more education has consistently been associated for the last fifty years in research with lower levels of authoritarianism, 
this effect appears apparently even in highly educated societies. Whatever the relation between education and authoritarianism (explanations were often not clear), it can be considered a main social influence on authoritarianism.

In a cross sectional analysis using the LISREL-procedure a rather simple model was tested. In this model authoritarianism was represented by authoritarian aggression and submission separately. It was hypothesized that rising levels of education would lead to lower levels of both authoritarian submission and aggression. These lower levels would then lead to more secularization (that is: less religious identification).

This model was indeed allowed by LISREL-analysis, with a slightly different, but interesting outcome (see Figure 1). Education showed a negative influence on both submission and aggression, but a stronger one on aggression. Aggression hardly influenced religious identification, but did influence submission considerably. Submission was most strongly and positively influenced by aggression, while the influence of education was less strong, but in a negative direction. This can be explained by assuming that education leads to lower levels of authoritarian submission, while aggression leads to higher levels of submission. Finally, secularization was finally most strongly influenced by submission, and hardly by aggression. When submission weakens, secularization will become stronger.

The finding that authoritarian submission could be a main factor influencing religious identification (or secularization), whereas authoritarian aggression only works indirectly through submission, may suggest a new perspective in analyzing the relation between religion and authoritarianism. Although some religions used violence in certain periods (the Spanish Roman Catholic inquisition, Iran's Islam fundamentalists), refraining from 'world' matters and from aggression seems a more general feature of most religions. Authoritarian aggression otherwise has never been rec-
Authoritarianism in The Netherlands: Mission Completed?

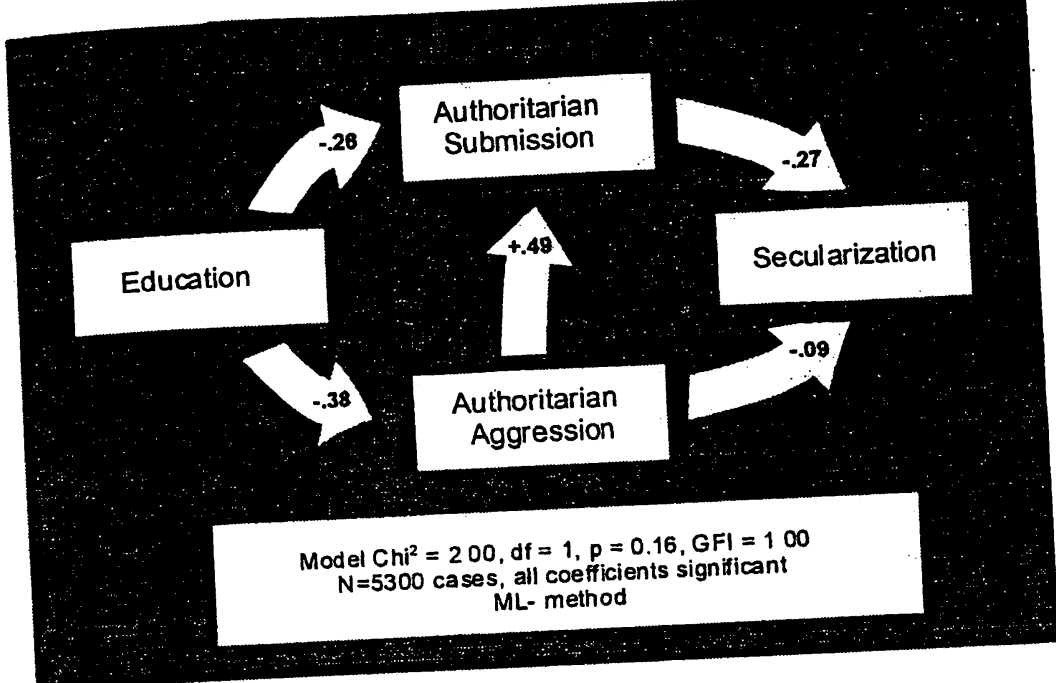

Figure 1. Authoritarianism between Education and Secularization

ognized as a relevant element in religious thinking. Submission, however, is recognized as such: submission toward the church or toward the worshiped God. The role of aggression seems not absent, but apparently increases submission. This would indicate one reason for the close relation between aggression and submission, once considered the core of authoritarianism: the sadomasochist element stressed originally by Fromm (1941). Aggression frightens people into submission, and as a result they will seek refuge, and some do so in religion. By contrast lack of authoritarian aggression, that is lack of personal and social fear, will in the end lead to less a need for submission and religion.

With more than fifty years of peace and prosperity in The Nethtogether with a lack of territorial or economic threat from outside, a lack of experienced aggression indeed may be a main factor leading to lower levels of authoritarianism. Unfor- 
tunately, this 'peace' factor cannot be operationalized with the Middendorp surveys. But some face validity seems to have been recognized abroad as 'Hollanditis': its (mainly assumed) history of trying to stay out of trouble, mostly European trouble.

This analysis, therefore, suggests that secularization may be the result of declining levels of authoritarian submission and aggression, which in turn can be the result of a better and higher educated population. This is a long range longitudinal effect, possibly related to a long-term-peace factor or a lack-of-threat factor.

\section{International Comparison}

\section{Introduction}

It is hard and almost impossible to interpret authoritarianism levels without information of these levels in other countries, regions or cultures. A preliminary inventory of authoritarianism levels was made earlier from hundreds of studies in authoritarianism (Meloen 1983). It included research from 24, mainly western countries, like the US, West European countries and some Third World countries. Ever since, data from additional countries have been collected (Meloen, Farnen, and German 1994a, 1994b; Farnen and Meloen, 2000). The cross-national results lead to a preliminary model for interpreting authoritarianism (Meloen 1996).

\section{The Low Level Hypothesis}

By using the mentioned international data we will explore hypothesis (3): The Netherlands is among the lowest in levels of authoritarianism and state authoritarianism in the world. The reason for this hypothesis is not petty local ethnocentrism, but the finding that with various authoritarianism scales Dutch students scored rather consistently low, from the first studies of the late 1960 s on. Their levels indicated even lower levels than their
American or European counterparts, although relative few studies were available, and cross national research was as a result not very well comparable. On the other hand, authoritarianism was widely recognized in many countries and often associated with dictatorial tendencies. This also leads to a need for the international comparison of authoritarianism levels.

We will make a distinction between authoritarian attitudes and state authoritarianism for reasons of clarity, in presenting the following results.

\section{Authoritarian Attitudes}

The first exploration of authoritarian attitudes concerns the authoritarianism measured by the included Middendorp F Scale. We will report here preliminary results from the international Meloen and Farnen database over the first 30 countries. Samples were included from North America, West and East Europe and Russia, Latin America, Africa and Asia, in all, with some 7500 respondents. We will first examine the reliability and validity coefficients of the used authoritarianism scales.

Three related versions of the F Scale were included: the seven item Middendorp scale (F7), an eight-item Eisinga \& Scheepers scale (Auth8), and a ten-item Meloen scale (Auth10). A reliability analysis showed substantial alpha's. This may suggest that the reliability of the authoritarianism scales does not disintegrate, when used in other countries and with international samples (Table 21). The over all reliability of the Middendorp F Scale is only slightly lower then in the Dutch random samples (of around .70). This is a most remarkable result. The European samples that answered translated questionnaires produced equal or even higher reliabilities, than the American samples that used the original version. Translation, therefore, does not seem to hinder the results in this respect. If the scales had been culture specific, then lower reliabilities would be inevitable in other cultures. But this 
does not seem to be the case. Obviously, Europeans have some experience with authoritarianism in their recent history, probably more so than Americans, who never lived under authoritarian government.

\section{Table 21. Reliability Authoritarianism over 30 Countries World Wide - 1991-1996}

$\begin{array}{lllllc} & \text { Nit } & \text { Alpha } & \text { Cit } & \text { N } & \text { Alpha-30 } \\ \text { Middendorp F7 } & 7 & .67 & .22 & 7441 & .90 \\ \text { Eisinga \& Scheepers Auth8 } & 8 & .75 & .27 & 7432 & .92 \\ \text { Meloen Auth10 } & 10 & .75 & .23 & 7044 & .90\end{array}$

Alpha = Cronbach Alpha; Nit = Number of Items in Scale; Cit = Mean Inter Item Correlation; $\mathrm{N}=$ Number of Respondents; all scales original Adorno items; Alpha-30 = reliability if the scale included 30 items of similar coherence

A number of indicators were included in the international survey that could indicate the concurrent validity of the three authoritarianism scale versions (Table 22). It was expected that authoritarianism was positively related to militarism, ratings of dictators (Hitler, Mao, Stalin, Saddam Hussein) and scaled self ratings of being right wing, militarist, conservative and authoritarian, while being negatively related to multiculturalism and scaled ratings of reformers (Nelson Mandela, Mahatma Gandhi, Martin Luther King and Gorbachev).

For all three authoritarianism scales this expectation is confirmed by the results. Although the correlations are not always very high, they are highly significant, and all of them in the expected direction. This suggests that authoritarianism has international dimensions and that it is possible to investigate it. This increases also the confidence in the used authoritarianism scales. Not shown here is that factor analysis revealed a strong first factor (also after varimax), which included amongst others most of the F Scale
76 items. This suggests again that the authoritarianism factor may indeed be very international.

Table 22. Authoritarianism and External Variables World Wide - 1991-1996

\begin{tabular}{|c|c|c|c|}
\hline & F7 & Auth8 & Auth 10 \\
\hline Multiculturalism & -23 & $-.24 \% * \%$ & $-.26 * \% *$ \\
\hline Militarism & $.44 \% * \%$ & $.47 * * * *$ & $.48 \div \% *$ \\
\hline Pro Dictator & $.24 \% * \%$ & $.24 \% \% *$ & $.25 \%$ \\
\hline Pro Reformer & $-.25 \% * \%$ & $-29 * * * * *$ & $-.31 * \% * *$ \\
\hline Self Right Wing & $20 \% * *$ & $.23 \% * \%$ & $27 * * * \%$ \\
\hline Nmin-max & $6398-6892$ & $6393-6883$ & $6357-6748$ \\
\hline
\end{tabular}

Pearson Correlations; 30 Countries; student samples mainly; Nminmax: Minimum and Maximum Number of Respondents; F7: F Scale Middendorp; Auth8: Authoritarianism Scale Eisinga \& Scheepers; Auth10: Authoritarianism scale Adorno et al. (includes items F7 and Auth8); $* * * *=p<.0001$

\section{Authoritarianism Levels}

We can now also explore the authoritarianism levels in the 30country analysis and assess if Dutch student samples show rather low levels (Table 23). The preliminary results, indeed, indicate that Dutch samples show very low levels, the lowest so far of all the samples included. In general, contrary to our expectations, most West European samples show low levels, even lower than American samples. American samples used to have lower levels than those of the Europeans in the 1960s and 1970s. Low levels were also found among (West) German samples. The West European samples in general showed low levels, compared to those from other continents. Especially samples from Africa, Russia and South Asia (not so much East Asia) were among the highest in our survey. East Europe, Latin America and East Asia show rather moderate authoritarianism levels. 
What these differences in levels mean is yet to be investigated. Levels in totalitarian or recently totalitarian countries were clearly But apart from political explatic with longer democratic traditions. lated as well. However, yet very extensive concluse explorative results do not warrant

Tenclusions, and need further research.

Table 23. Authoritarianism World Wide - F Scales 1991-1996

\begin{tabular}{llclclc} 
& F7 & \multicolumn{3}{l}{ Auth8 } & \multicolumn{2}{c}{ Auth10 } \\
USA & Mean & $\mathbf{N}$ & Mean & N & Mean & N \\
West Europe & 4.01 & 1205 & 4.03 & 1200 & 4.06 & 1192 \\
$\quad$ Netherlands & 3.38 & 2100 & 3.27 & 2097 & 3.47 & 1739 \\
East Europe & 2.77 & 443 & 2.57 & 443 & 2.80 & 100 \\
Russia & 4.27 & 1849 & 4.36 & 1847 & 4.39 & 1843 \\
Latin America & 4.57 & 879 & 4.73 & 877 & 4.75 & 873 \\
Africa & 4.23 & 313 & 4.40 & 315 & 4.30 & 310 \\
Asia & 4.81 & 192 & 4.90 & 192 & 4.79 & 192 \\
Total & 4.32 & 903 & 4.28 & 904 & 4.25 & 895 \\
& 4.03 & 7441 & 4.05 & 7432 & 4.14 & 7044
\end{tabular}

Authoritarianism Scale Eisinga \& Scheepers; Auth10 $=$ F Scale Middendorp; Auth8 $=$ et al. (includes F7 and F8 items)

\section{State Authoritarianism}

In a recent approach is the concept of state authoritarianism was developed (Meloen 1996, 2000). This concept is not assessed in ions of individual the performance of states world wide. The from information on one by Freedom House, that produc The oldest approach is the 'freedom rating' for that produces since the early 1980s a rating includes both civil rights and countries in the world. This is related, but since Freedom the civil liberties. Our approach final results, statistical analysis of $(1993,1995)$ only publishes Using other internations of their concept was not possible. authoritarianism scalnational sources, a ten-item state 78
Authoritarianism in The Netherlands: Mission Completed?

lowing ratings: trade unions being illegal or not, the existence of state terror practices, state suppression of deviation, and state beliefs being imposed, the legal tolerance of homosexuality, the existence of state censorship, the use of capital punishment, the status of abortion being legal or not, the number of military per 100 Physicians, and repression of the opposition (holding prisoners of conscience, and being obstructive to human rights bodies; see Meloen 1996 for details).

The tested reliability of this state authoritarianism scale was quite high for a short scale in a pilot study (alpha: .85, over 52 countries). Adding countries did not dramatically decrease this value (final alpha: .83, over 95 countries). The included ratings are taken from independent sources, and therefore a similar judgment of the raters cannot have improved this reliability. Also, most of the important countries were included and only some minor ones were missing (due to some missing ratings). Much of the data relates to the situation of the early 1990s, when many authoritarian and totalitarian governments were still in power.

From this state authoritarianism scale the levels were computed for each country (Meloen 1996, preliminary scores; Meloen 2000, definite scores). This was also done in order to explore the discriminant validity of the scale. High levels of state authoritarianism should be associated with dictatorship and authoritarian or totalitarian government. This appeared to be the case. The definite score runs from zero or low state authoritarianism to 100 or high state authoritarianism. Among the countries with high levels of state authoritarianism appears Iran (93), Laos, Burma (89), Ethiopia (86), Sudan (85), and Libya (83), all countries, at the time, noted for authoritarian types of government in one way or another. Laos and Ethiopia have since become more democratic, but the other ones still remain among the most dictatorial ones. High scores were also found for communist countries (Soviet Union 60, China 63) and Apartheid South Africa (63). 
Most democratic countries showed indeed low levels, although there is some variation here too. Among the lowest is The Netherlands (0), Canada (3), Iceland (3), Scandinavia (Denmark and Sweden 10, Norway 12) and New Zealand (12), countries known for their liberal and democratic climate. It should be noted that lands, or judged country ratings originated in The Netherlands, or from Dutch judges. Most western countries tended to have low scores as well (USA 18, France 10, Germany 12, UK 34, Japan 22). Not surprisingly, the state authoritarianism scale also correlated highly with the Freedom House ratings.

For our present exploration it is important that the state authoritarianism scale shows considerable discriminant validity, and that we can employ this scale with some confidence here. A very liberal climate indeed is available among a number of states in the right direction it is mate students show it is understandable that in a liberal cliMany of them never experienced auth authoritarianism levels. known from history books. climates and less absorbed the norms andratic traditions students may not have and therefore do notues of liberal and democratic society correlation between this state authoritarianianism. A high ian attitudes of our this state authoritarianism and authoritarputed, suggesting international samples has indeed been compected. Further research is relation between them, as can be exthis rather unique finding.

\section{Conclusions Low Level Hypothesis}

The mentioned indicators all show that The Netherlands rank the only country in state authoritarianism, but also that it is not are found in Scandin such low levels. Similar very low levels in those countries lowia, Iceland, Canada and New Zealand. If
Authoritarianism in The Netherlands: Mission Completed?

authoritarian (or better: high levels of non authoritarian) attitudes, this would not be surprising, considering the presented results. These last conclusions are not final, but strongly indicated by this analysis. The third hypothesis, therefore, seems to receive support as well.

\section{Conclusions}

In this analysis three basic hypotheses on authoritarianism were tested. A composite Middendorp data set was used, including five national random samples in The Netherlands: 1970, 1975, 1980, 1985 and 1992 (Middendorp 1978, 1991). These surveys totaled more than nine thousand respondents. Thirty authoritarianism related items, including eight original Adorno et al. items, were used in nine operationalizations of authoritarianism. In most analyses the Middendorp F Scale was used. The various operationalizations were mainly based on Adorno et al. (1950) and Altemeyer (1988). Most of the nine operationalizations showed adequate reliabilities (alpha's of .71 to .87 ), and satisfactory coefficients of concurrent validity, discriminant validity and explanatory validity, consistent with those reported in the literature (Meloen 1983, 1993, Meloen and Middendorp 1991). The longer authoritarianism scales showed typically higher reliabilities and validity coefficients.

Hypothesis (1) - the authoritarianism syndrome will not disintegrate in time (stability-hypothesis) - was strongly supported. This hypothesis was tested by comparing the reliabilities of authoritarianism operationalizations in time, by comparing main validity coefficients in time, and by comparing the relationships with social variables in time. The reliabilities of the nine authoritarianism scales did not decrease in time, and showed considerable stability. Some of the main validity coefficients (nationalism, anti freedom attitudes, anti democratic attitudes, ano$\mathrm{mia}$ ) also did not show any weakening in time, and finally the social variables (education, education father, age, self rating of 
social class) mainly showed stable relationships in time. This was the case for the short Middendorp F Scale, as well as for the wider authoritarianism syndrome. It was concluded that there does not seem to be any sign of weakening of the authoritarianism syndrome: a syndrome of related authoritarian attitudes and opinions. This is remarkable, considering the support for the next hypothesis.

Hypothesis (2) - the levels of authoritarianism have steadily decreased in time (decreasing levels-hypothesis) - was tested by comparing the authoritarianism levels (group scale means) in time. It was shown that the levels of the various operationalizations of authoritarianism have all decreased since the first survey of 1970 , in a rather linear, and consistent way. Since the mid eighties all the authoritarianism levels have moved to the non authoritarian side. This indicates that non authoritarian attitudes are now supported among a majority of the population. The age cohorts seem to indicate that this trend will not easily change in the near future. Only an insignificant small rise was noted among the youngest age groups.

Considering the stark support for hypothesis (1), it is argued that the decrease of authoritarianism levels cannot be attributed to disintegration of the authoritarianism syndrome proper, the 'tainting' or 'wearing out' of the used items or scales. Therefore, this hypothesis (2) is well supported in the period covered by the five Middendorp surveys.

Finally, hypothesis (3) - The Netherlands is among the lowest in levels of authoritarianism and state authoritarianism in the world (low level-hypothesis) - was explored using the Meloen state authoritarianism analysis $(1996,2000)$ and the Meloen and Farnen 30 countries database, which included the same Middendorp authoritarianism scale. All indicators, indeed, show that the Dutch population rank among the lowest in authoritarian attitudes and The Netherlands among the lowest in state authoritarianism, together with the Scandinavian countries, Iceland, Canada and New Zealand.

These results seem to indicate that the quest Adorno et al. (1950) departed upon may have been completed in The Netherlands. The objective of a low authoritarian, or non authoritarian, society now seems to have been realized. The authoritarianism syndrome, however, has not disintegrated and is still present. It can be demonstrated empirically. Considering the steadily decreasing levels of authoritarianism in the past decades in this country, we may conclude from the results that Dutch society and its people have changed considerably. They may now be at the forefront of the world's most non authoritarian societies.

The preliminary analysis of the longitudinal trend may suggest that rising levels of education are partly responsible for this decrease of authoritarianism. It is argued, however, that a main influence that could not be included in this analysis, might be a general situation of prolonged peace and lack of territorial and an economic threat. Such factors may induce or facilitate a trend toward a non authoritarian, democratic society as well. It should be mentioned also that in this respect a number of rival hypotheses remain.

The general results of this analysis also should be considered with some caution. History has shown that in times of less prosperity authoritarianism can be on the rise again. In fact, the Altemeyer (1988) time series showed that among North American students such a rise occurred during the 1980 s. Additionally, where American students scored very low in the late 1960s and 1970s (Meloen 1983), such low scores have hardly been found recently (Farnen and 2000). In the 1990s the West European students and Meloen, 2000 . This may indeed indicate that the presented trend toward less authoritarianism can be reversed in changing circumstances. This could be a warning for too optimistic conclusions from this analysis. 


\section{Acknowledgments}

My gratitude goes to the late Cees Middendorp, Erasmus University of Rotterdam and to the Amsterdam Steinmetz Archives for providing the data sets for this analysis.

\section{References}

Adorno, T.W., E. Frenkel-Brunswik, D.J. Levinson, and R.N Sanford. 1950. The Autboritarian Personality. New York:
Harper \& Row.

Altemeyer, B. 1988. Enemies of Freedom. London: Jossey Bass. Altemeyer, B. 1996. The Authoritarian Specter. Cambridge,
Massachusetts: Harvard University Press.

Diab, L.N. 1959. Authoritarianism and Prejudice in Near-Eastern Students Attending American Universities. Journal of Social Psychology, 50, 175-187.

Duckitt, J. 1992. Education and Authoritarianism Among English- and Afrikaans-Speaking White South Africans. Journal of Social Psychology, 132, 701-708.

Farnen, R.F., J.D. Meloen. 2000 (in press). Democracy, Author ity, and Education: A Cross-National Empirical Survey. LonPress.

Freedom House Survey Team. 1993. Freedom in the World: The Annual Survey of Political Rights and Civil Liberties 1992-1993. New York: Freedom House.

Freedom House Survey Team. 1995. Freedom in the World: Annual Survey of Political Rights and Civil in the World: The New York: Freedical Rights and Civil Liberties 1994-1995.

Fromm, E. 1941/1965. Escape Books.

Fukuyama, F. 1992. The End of History and the Last Man. London: Penguin Books, p. 49-50.
Lederer, G. 1982. Trends in Authoritarianism: A Study of Adolescents in West Germany and the United States Since 1945. Journal of Cross-Cultural Psychology 13, 3, 299-314.

Lederer, G. 1983. Jugend und Autorität: Ueber den Einstellungswandel zum Autoritarismus in der Bundesrepublik Deutschland und den USA [Youth and Authority: About the Attitudes on Authoritarianism in the Bundesrepublik and the USA]. Westdeutscher Verlag, Opladen.

Meloen, J.D. 1983. De autoritaire reactie in tijden van welvaart en crisis. [The Authoritarian Response in Times of Prosperity and Crisis]. Amsterdam: University of Amsterdam, unpublished dissertation.

Meloen, J.D. 1991. The Fortieth Anniversary of 'The Authoritarian Personality'. Politics and the Individual, 1, 119-127.

Meloen, J.D. 1993. The F Scale as a Predictor of Fascism: An Overview of 40 Years of Authoritarianism Research. Pp. 4769 in Strength and Weakness: The Authoritarian Personality Today by W.F. Stone, G. Lederer, and R. Christie. New York: Springer Verlag.

Meloen, J.D. 1994. A Critical Analysis of Forty Years of Authoritarianism Research. Pp. 127-165 in Nationalism, Ethnicity and Identity: Cross-National and Comparative Perspectives, edited by Russell Farnen. Transaction Books, New York.

Meloen J.D. 1996. Authoritarianism, Democracy, and Education: A preliminary Empirical 70-Nation Global Indicators Study. Pp. 20-38 in Democracy, Socialization and Conflicting Loyalties in East and West: Cross-National and Comparative Perspectives, edited by Russell Farnen, Henk Dekker, Daniel German and Rudiger Meyenberg. Houndsmill, UK: MacMillan Press.

Meloen, J.D. 2000 (in press). The Political Culture of State Authoritarianism. Pp. 108-127 in Political Psychology: Cultural and Cross Cultural Foundations, edited by S. Renshon and J. Duckitt. London, UK: Macmillan. 
Meloen, J.D., R. Farnen, and D. German. 1994. Authoritarianism and Democracy: Evidence from Twelve Countries World Wide. Pp. 123-152 in From Subject to Citizen, edited by G. Csepeli, D. German, L. Keri, I. Stumpf. Budapest: Hungarian Center for Political Education - Friedrich-Naumann Stiftung.

Meloen, J.D., R. Farnen, and D. German. 1994. Authoritarianism, Democracy and Symbolic Political Leadership in the New World Order. Pp. 255-281 in Political Consciousness and Civic Education during the Transformation of the System, edited by R. Holly. Warsaw: Institute of Political Studies, Polish Academy of Sciences.

Meloen, J.D., L. Hagendoorn, Q. Raaijmakers, and L. Visser. 1988. Authoritarianism and the Revival of Political Racism: Reassessments in The Netherlands of the Reliability and Validity of the Concept of Authoritarianism by Adorno et al. Political Psychology 9, 3, 413-429.

Meloen, J.D., G van der Linden, and H. de Witte. 1994. Authoritarianism and Political Racism in Belgian Flanders: A Test of the Approaches of Adorno et al., Lederer and Altemeyer. Pp. 72-108 in Political Consciousness and Civic Education during the Transformation of the System, edited by R. Holly. Warsaw: Institute of Political Studies, Polish Academy of Sciences.

Meloen, J.D., and C.P. Middendorp. 1985. Potentieel fascisme in Nederland [Potential Fascism in The Netherlands]. Pp. 93-108 in Jaarboek van de Nederlandse Vereniging van Marktonderzoekers. Haarlem: De Vrieseborgh.

Meloen, J.D., and C.P. Middendorp. 1991. Authoritarianism in The Netherlands: Ideology, Personality or Sub Culture. Politics and the Individual, 1, 2, 49-72.

Middendorp, C.P. 1978. Progressiveness and Conservatism: The Fundamental Dimensions of Ideology Controversy and their Relationship to Social Class. The Hague: Mouton Publishers.

Middendorp, C.P. 1991. Ideology in Dutch Politics: The Demo-
Shils, E.A. 1954. Authoritarianism: "Left" and "Right". Pp. 24 49 in Studies in the Scope and method of "The Autboritarian Personality", edited by R. Christie and M. Jahoda. Glencoe: The Free Press.

Simpson, M. 1972. Authoritarianism and Education: A Comparative Approach. Sociometry, 35, 223-234.

Stone, W.F., G. Lederer, and R. Christie. 1993. Strength and Weakness: The Authoritarian Personality Today. New York: Springer. 


\section{Appendix}

\section{Content of the Used Scales}

The text of a complete scale item appears only once; thereafter the item is represented by key words only (printed in italics). Text/ translations according to Middendorp 1978, Adorno et al. 1950. For Reliabilities, see Tables. Answer categories: mostly 5 or 7; specific information: see Middendorp 1978.

Scale Authoritarianism F30

1. Wishes abortion - If a woman so wishes, it should be possible for her to have an abortion.

2. Death penalty - It might be a good thing to reintroduce the death penalty for certain crimes. 3. Teenagers obey - It is mostly for the good of teenagers that they
obey their parents.

4. Obedience - The most important thing children should learn is total obedience to their parents wishes.

5. Show regard - Obviously a child should show regard and respect for their parents.

6. Woman children - A woman is more capable of bringing up small cbildren than a man.

7. Woman over men - In a firm it is unnatural when a woman hold a position of authority over men.

8. Good schooling - It is not so important for a girl to get a good schooling as it is for a boy.

9. Boys more freely - Boys can be raised more freely than girls.

10. Bad manners - A person who has bad manners, habits and 11. Prying - hardly expect to get along with decent people. matters that - Nowadays more and more people are prying into 12. Devoted leader remain personal and private.

12. Devoted leaders - What we need are fewer laws and instituthe people can put their faith.
13. Immoral people - Most of our social problems would be solved if we could somehow get rid of the immoral, crooked and feebleminded people.

14. Rebellious ideas - Young people sometimes get rebellious ideas, but as they grow up, they ought to get over them.

15. Familiarity - Most people fall short of your expectations if you get to know them better (familiarity breeds contempt).

16. Weak and strong - There are two kinds of people: the weak and the strong.

17. Send aid - The government should: [send] aid to developing countries.

18. Aid countries - If everybody would give up $1 \%$ of his income for aid to developing countries, would you think that too much, too little or just about right?

19. Woman bousebold - Do you, or don't you object to a woman with children who go to school, having a job in addition to her bousebold duties, or is this to be recommended?

20. Work day-nursery - Following item 19: And when there are children at home that would have to be sent to a day-nursery?

21. Not children - A married couple decides on principle not to have children although there are no medical objections. Can you approve of such a point of view or do you think it is unacceptable?

22. Say you - Are you for or against children addressing their parents as 'you' (instead of 'thou')?

23. Read anytbing - Do you think a 18-year old boys and girls should be allowed to read anything they like or do you think that some books might be unfit?

24. Tell girl bome - Do you think that the parents of , say a 20year old girl, should tell her at what time she has to be back bome at night, or do you think it better that they leave it to their daughter's discretion?

25. Homosexuals firmly - Homosexuals should be firmly dealt with 26. Homosexuals eliminated - Homosexuals should be eliminated from society 
27. Sexual intercourse - I think that a girl can have full sexual intercourse with a boy even if she doesn't care for him.

28. Abortion allowed - Are there circumstances in which abortion should be allowed?

29. Eutbanasia - Suppose a physician is able to put a patient out of his misery, at his own request, by giving him an injection. What do you think he should do?

30. Homosexuals opposed - Do you think that bomosexuals should be left free as free as possible to live their own life, or do you feel that this should be opposed as much as possible?

Scale Authoritarianism (F7 - Middendorp): 1. Weak and strong, 2. Familiarity, 3. Rebellious ideas, 4. Immoral people, 5. Devoted leaders, 6. Bad manners, 7. Prying

Scale Authoritarianism (AUTH8 - Eisinga \& Scheepers): 1. Weak and strong, 2. Familiarity, 3. Rebellious ideas, 4. Immoral people, 5. Devoted leaders, 6. Bad manners, 7. Sex crimes - Sex crimes, such as rape and attacks on children, deserve more than mere imprisonment; such criminals ought to be publicly whipped or worse, 8. Talk less - If people would talk less and work more, everybody would be better off.

Scale Authoritarianism (AUTH10 - Meloen \& Farnen): 1. Weak and strong, 2. Familiarity, 3. Rebellious ideas, 4. Immoral people, 5. Devoted leaders, 6. Bad manners, 7. Prying, 8. Sex crimes, 9. Talk less, 10. Force to save - Our true and traditional way of life is disappearing so fast that we may have to use force to save it.

Scale Authoritarianism (F10): 1. Bad manners, 2. Prying, 3. Devoted leaders, 4. Immoral people, 5. Rebellious ideas, 6. Familiarity, 7. Weak and strong, 8. Homosexuals firmly, 9. Obedience, 10. Death penalty.
Scale Authoritarianism (F16): 1. Death penalty, 2. Teenagers obey, 3. Obedience, 4. Show regard, 5. Woman children, 6. Woman over men, 7. Good schooling, 8. Boys more freely, 9. Bad Manners, 10. Devoted leaders, 11. Immoral people, 12. Rebellious ideas, 13. Familiarity, 14. Weak and strong, 15. Homosexuals firmly, 16. Homosexuals eliminated.

Scale Authoritarianism (ALT18 - Altemeyer concept, Middendorp items)

1. Authoritarian Conventionalism (CONV6): 1. Women more capable, 2. Good schooling, 3. Bad manners, 4. Familiarity, 5. Not cbildren, 6. Sexual intercourse.

2. Authoritarian Submission (SUBM6): 7. Obedience, 8. Show regard, 9. Teenagers obey, 10. Devoted leaders, 11. Rebellious ideas, 12. Weak and strong.

3. Authoritarianism Aggression (AGR6): 13. Death penalty, 4. Woman authority, 15. Boys more freely, 16. Immoral people, 17. Homosexuals firmly, 18. Homosexuals eliminated.

Scale Right Wing Extremism (REX11): 1. Death penalty, 2. Good schooling, 3. Boys more freely, 4. Bad manners, 5. Prying, 6. Devoted leaders, 7. Immoral people, 8. Familiarity, 9. Weak and strong, 10. Send aid, 11. Aid countries.

Scale Anti Feminism (AFEM4): 1. Women children, 2. Woman over men, 3. Good schooling, 4. Boys more freely.

Scale Parental Attitudes toward Children (PARENTS 3): 1. Teenagers obey, 2. Obedience, 3. Show regard.

Scale Attitudes towards Children (CHIID 6): 1. Woman bousebold, 2. Work day-nursery, 3. Not children, 4. Say 'you', 5. Read everytbing, 6. Tell girl bome 
Scale Anti Homosexuality (AHOMO3): 1. Homosexuals firmly, 2. Homosexuals eliminated, 3. Homosexuals opposed.

Scale Anti Freedom Attitudes (UNFREE7)

1. Demonstrate - Should you be free to demonstrate for or against something?

2. Criticize - Should you be free to criticize openly members of the Royal Family?

3. Strike - Should you be free to strike for pay rises?

4. Conscientious objector - Should you be free to a conscientious objector?

5. Occupy building - Should you be free to occupy buildings (e.g. schools, universities) in order to enforce justified demands?

6. Write whatever - Should you be free to write whatever you like in public?

7. Say whatever - Should you be free to say whatever you like in public?

\section{Scale Anti Democratic Attitudes (UNDEMO3)}

1. Student's say - Do you think that the student's say in management of the university should increase or lessen?

2. Say of pupils - Do you think that the say of pupils in secondary schools and training colleges should increase or lessen?

3. Citizens say - Do you think that the citizen's say in government of towns and provinces should increase or lessen?

Scale Nationalism (NAT4)

1. Better country - Generally speaking, The Netherlands is a better country than most other countries.

2. Instilling patriotism - Instilling patriotism in pupils is an important educational task.

3. Respect flag - Every Dutchman should show the necessary respect towards out national symbols such as the flag and the national anthem.
4. Dutch ways - When striving for international cooperation, we

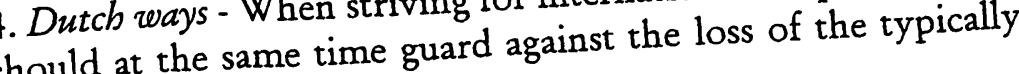
Dutch ways of life.

Scale Anomia (ANOMIA5)

1. Many opinions - There are so many opinions about what is right and what is wrong that you hardly know where you stand. 2. Things change - Things change so rapidly these days that often you hardly know what is right and what is wrong.

in - The future is so uncertain that it is best to live from day to day.

4. Need luck - To be successful in society one needs a lot of luck. 5. Who trust - You hardly know who you can trust nowadays. 